\title{
Factors Associated with Metastatic Lymph Node Ratio, Extranodal Extension in the Central Compartment Node-Positive Papillary Thyroid Carcinoma
}

\author{
Chan Woo Park ${ }^{1}$, Jun Woong Song ${ }^{1}$, Bong Kwon Chun ${ }^{2}$, Sung Won Kim¹, \\ Hyoung Shin Lee ${ }^{1}$, Jong Chul Hong ${ }^{3}$, and Kang Dae Lee ${ }^{1}$ \\ ${ }^{1}$ Departments of Otolaryngology-Head and Neck Surgery, ${ }^{2}$ Pathology, Kosin University College of Medicine, Busan; and \\ ${ }^{3}$ Department of Otolaryngology-Head and Neck Surgery, Dong-A University College of Medicine, Busan, Korea
}

\author{
중심 경부 림프절 전이가 있는 갑상샘 유두암에서 전이 림프절 비율, \\ 림프절 피막외 침범의 관련 인자 분석 \\ 박찬우 ${ }^{1} \cdot$ 송준웅 $^{1} \cdot$ 천봉권 $^{2} \cdot$ 김성원 $^{1} \cdot$ 이형신 $^{1} \cdot$ 홍종철 $^{3} \cdot$ 이강대 $^{1}$ \\ 고신대학교 의과대학 이비인후과학교실, ${ }^{1}$ 병리학교실, ${ }^{2}$ 동아대학교 의과대학 이비인후과학교실 ${ }^{3}$
}

\author{
Received February 12, 2015 \\ Revised March 27, 2015 \\ Accepted March 31, 2015 \\ Address for correspondence \\ Kang Dae Lee, MD, PhD \\ Department of Otolaryngology- \\ Head and Neck Surgery, \\ Kosin University \\ College of Medicine, \\ 262 Gamcheon-ro, Seo-gu, \\ Busan 602-702, Korea \\ Tel $+82-51-990-6470$ \\ Fax $+82-51-245-8539$ \\ E-mail kdlee59@gmail.com
}

Background and Objectives Lymph node (LN) metastasis occurs in $30-80 \%$ of patients presenting for initial treatment of papillary thyroid carcinoma (PTC). The presence of LN metastasis is an independent risk factor for recurrence, which can add significant treatment morbidity. The LN ratio (LNR) and extranodal extension (ENE) have been shown to be important prognostic factors in PTC. The purpose of this study was to assess the characteristic features of LNR and ENE.

Subjects and Method We undertook a retrospective study of 411 patients treated between January, 2011 and December, 2013 for central compartment node-positive PTC by thyroidectomy and central compartment neck dissection (CCND) at our institution. We compared various clinicopathologic parameters such as age, gender, tumor size, multifocality, bilaterality, local invasion, extrathyroidal extension and aggressive variants between LNR and ENE.

Results The significant associated factors for high LNR (defined as higher than 0.5 ) in multivariate analysis were gender $(p=0.001$, odds ratio $=2.285)$ and multifocality $(p=0.027$, odds ratio $=2.092)$. On the other hand, the significant associated factors for ENE in multivariate analysis were primary tumor size $(p=0.023$, odds ratio $=1.965)$ and local invasion $(p=0.043$, odds ratio=1.870).

Conclusion Being male, multifocality, large primary tumor size (defined as larger than $1 \mathrm{~cm}$ ) and local invasion were revealed as associated factors for LNR and ENE. Therefore, elective CCND should be considered for patients with PTC, for whom a thorough investigation of associative factors should be made before surgery.

Korean J Otorhinolaryngol-Head Neck Surg 2015;58(7):475-80

Key Words Lymphatic metastasis - Papillary carcinoma - Thyroid neoplasm.

\section{서 론}

갑상샘 유두암은 5년 생존율이 94\% 이상인 경과가 양호한 암으로 알려져 있다.1) 그러나 갑상샘 유두암은 경부 림프절 전
이의 빈도가 매우 높게 발생하여 초진 시 경부 림프절 전이가 $30 \%$ 에서 $80 \%$ 정도까지 발견되고, ${ }^{1)}$ 임상적으로 경부 림프절 전이가 촉지되지 않는 경우에도 미세 림프절 전이 빈도가 $21 \%$ 에서 $82 \%$ 까지 보고되고 있다. ${ }^{2)}$ 림프절 전이가 생존율에 미 
치는 영향은 보고자마다 차이가 있어 ${ }^{34)}$ 림프절 전이는 생존 율의 예측인자라기보다는 국소 재발의 독립적인 위험인자로 간주되고 있다. ${ }^{5)}$ 그러나 분화 갑상샘암의 국소 재발은 기관 (trachea), 식도, 되돌이 후두신경, 총경동맥, 내경정맥 등 주 요 구조물이 위치한 경부에서 빈번히 일어나므로 이는 환자 의 삶의 질에 실제적인 영향을 미친다고 할 수 있다.

림프절 전이에 영향을 미치는 요인들로는 나이, 조직학적 분 류, 갑상샘 피막외 침범, 원격전이, 갑상샘 종양의 크기, 다발 성, 성별 등이 있다.67) 최근 연구들에 따르면 위암, 대장암에 서는 중요한 예후인자이지만 갑상샘 유두암에서는 상관관계 가 불명확하였던 전이 림프절 비율(lymph node ratio)과 림프 절 피막외 침범(extranodal extension)이 국소 재발률에 의미 있는 예후 인자들로 보고되고 있다. ${ }^{8-12)}$ 이에 본 연구는 갑상 샘 유두상의 적절한 수술 범위 및 치료 전략을 수립하기 위해 갑상샘 유두암에서 전이 림프절 비율과 림프절 주변조직 침 습의 임상양상과 관련되는 인자들을 알아보고자 본 연구를 시행하였다.

\section{대상 및 방법}

\section{대 상}

2011년 1월부터 2013년 12월까지 본원 이비인후과에서 갑 상샘 절제술과 중심 경부 림프절 절제술을 함께 받은 1154 명 의 환자 중에서 병리학적으로 갑상샘 유두암으로 진단되고 최소한 한 개 이상의 림프절을 획득하여 한 개 이상의 림프 절 전이가 확인된 411 명을 대상으로 의무 기록과 조직병리기 록을 참고하여 후향적으로 분석하였다. 병리학적으로 림프 절 전이가 확인되더라도 전이 림프절 수나 획득한 전체 림프 절 수가 불명확한 경우는 제외하였으며 재발 후 완성형 갑상 샘 절제술을 시행한 경우도 연구 대상에서 제외하였다.

임상적으로 림프절 전이나 갑상선외 침범이 없는 단발성의 미세 갑상샘 유두암의 경우 엽절제술을 시행하였으며 그 외 에는 전절제술을 시행하였다. 모든 환자에서 중심 경부 림프 절 절제술을 시행하였으며 동측의 기관 주위 림프절(paratracheal)과 기관 앞 림프절(pretracheal) 절제술이 원칙이나 수 술 전 양측 갑상샘 유두암으로 진단받은 경우에는 양측 중앙 림프절 절제술을 시행하였다.

\section{방 법}

모든 환자에 있어 성별, 나이, 종양의 다발성, 양측성, 갑상 샘 피막외 침범 유무, 종양의 크기, 국소 침윤(local invasion), 공격적 변이종(diffuse sclerosing variant, tall cell variant, solid variant, columnar cell variant), 전이 림프절 비율, 림
프절 피막외 침범과 같은 임상병리학적 특징에 대하여 후향 적 연구를 시행하였다. 절제된 중심 경부 림프절에 대한 전이 된 림프절의 비율을 구하여 그 비율이 $1 / 2$ 미만인 군과 $1 / 2$ 이상인 두 군으로 나누어 임상양상 차이 여부를 확인하였고 전이 림프절에서 림프절 피막외 침범의 유, 무에 따라 두 군 으로 나누어 임상양상 차이 여부를 확인하였다. 결과에 대한 통계적 검증을 위해 IBM SPSS statistics version 22.0(IBM, Armonk, NY, USA)을 사용하였으며 chi-square test를 통하 여 단변량 분석(univariate analysis)을 시행하였고, 이를 바탕 으로 이분형 로지스틱 회귀 분석(binary logistic regression test)을 통해 다변량 분석(multivariate analysis)을 시행하였 다. 유의수준은 $p$-value 0.05 이하로 하였다.

\section{결 과}

환자는 남자가 94예(22.9\%), 여자가 317예(77.1\%)였으며,

Table 1. Patient clinicopathologic characteristics $(n=411)$

\begin{tabular}{lc}
\hline \multicolumn{1}{c}{ Characteristics } & Number of patients (\%) \\
\hline Age & $166(40.4)$ \\
$<45$ yrs & $245(59.6)$ \\
$\geq 45$ yrs & \\
Gender & $94(22.9)$ \\
$\quad$ Male & $317(77.1)$ \\
Female & \\
Size of primary tumor & $173(42.1)$ \\
$<1$ cm & $238(57.9)$ \\
$\geq 1$ cm & \\
Extrathyroidal extension & $162(39.4)$ \\
No & $249(60.6)$ \\
Yes & \\
Multifocality & $239(58.2)$ \\
No & $172(41.8)$ \\
Yes & \\
Bilaterality & $285(69.3)$ \\
No & $126(30.7)$ \\
Yes & \\
Local invasion & \\
No & $340(82.7)$ \\
Yes & $71(17.3)$ \\
Aggressive variants & \\
No & $393(95.6)$ \\
Yes & $18(4.4)$ \\
Nymph node ratio & \\
\hline 0.5 & \\
\hline
\end{tabular}


연령은 14세에서 80세까지로 평균 47.2세였다. 종양의 크기 가 $1 \mathrm{~cm}$ 미만인 경우가 173예(42.1\%)였고 $1 \mathrm{~cm}$ 이상은 238예 (57.9\%)였다. 갑상샘 피막외 침범(extrathyroidal extension) 은 249예(60.6\%)에서 나타났으며 종양의 다발성을 보인 경우 는 172예(41.8\%)였고 양측성을 보인 경우는 126예(30.7\%)였 다. 국소 침윤(local invasion)은 71예(17.3\%)에서 나타났고 공 격적 변이종(aggressive variants)은 18예(4.4\%)에서 나타났다. 절제된 중심 경부 림프절에 대한 전이 림프절의 비율이 $1 / 2$ 이 하가 221예(53.8\%)였고 1/2 이상은 190예(46.2\%)였다. 림프절 피막외 침범은 86예(20.9\%)에서 나타났다(Table 1).

절제된 중심 경부 림프절에 대한 전이 림프절의 비율(lymph node ratio)에 영향을 미치는 임상 및 조직학적 인자를 분석
하였는데 단변량 분석에서는 성별 $(p=0.001)$, 갑상샘 피막외 침범 $(p=0.027)$, 종양의 다발성 $(p=0.002)$, 양측성 $(p=0.036)$ 과 통계학적으로 유의한 상관관계를 나타내었다(Table 2). 다변 량 분석에서는 남성 $\{p=0.001$, odds ratio $=2.285[95 \%$ confidence interval(CI), 1.415 3.689]\}, 종양의 다발성 $[p=0.027$, odds ratio $=2.092(95 \% \mathrm{CI}, 1.086 \sim 4.030)]$ 이 전이된 림프절의 비율과 통계학적으로 유의한 상관관계를 나타내었다(Table 3).

림프절 피막외 침범(extranodal extension)은 단변량 분석 에서는 성별 $(p=0.034)$, 원발부위 크기 $(p=0.0002)$, 갑상샘 피 막외 침범 $(p=0.0002)$, 국소 침윤 $(p=0.0001)$ 과 통계학적으로 유의한 상관관계를 나타내었다(Table 4). 다변량 분석에서는 원발부위 크기 $[p=0.023$, odds ratio=1.965(95\% CI, 1.096

Table 2. Univariate analysis of clinicopathologic factors related to lymph node ratio

\begin{tabular}{|c|c|c|c|}
\hline Characteristics & Lymph node ratio $(<0.5)$ & Lymph node ratio $(\geq 0.5)$ & $p$ value \\
\hline \multicolumn{4}{|l|}{ Age } \\
\hline$<45$ yrs & $84(50.6 \%)$ & $82(49.4 \%)$ & \multirow{2}{*}{0.289} \\
\hline$\geq 45 \mathrm{yrs}$ & $137(55.9 \%)$ & $108(44.1 \%)$ & \\
\hline \multicolumn{4}{|l|}{ Gender } \\
\hline Male & $36(38.3 \%)$ & $58(61.7 \%)$ & \multirow{2}{*}{$0.001^{*}$} \\
\hline Female & $185(58.4 \%)$ & $132(41.6 \%)$ & \\
\hline \multicolumn{4}{|l|}{ Size of primary tumor } \\
\hline$<1 \mathrm{~cm}$ & $100(57.8 \%)$ & $73(38.4 \%)$ & \multirow{2}{*}{0.162} \\
\hline$\geq 1 \mathrm{~cm}$ & $121(50.8 \%)$ & $117(49.2 \%)$ & \\
\hline \multicolumn{4}{|l|}{ Extrathyroidal extension } \\
\hline No & $98(60.5 \%)$ & $64(39.5 \%)$ & \multirow{2}{*}{$0.027^{*}$} \\
\hline Yes & $123(49.4 \%)$ & $126(50.6 \%)$ & \\
\hline \multicolumn{4}{|l|}{ Multifocality } \\
\hline No & $144(60.3 \%)$ & $95(39.7 \%)$ & \multirow{2}{*}{$0.002^{*}$} \\
\hline Yes & $77(44.8 \%)$ & $95(55.2 \%)$ & \\
\hline \multicolumn{4}{|l|}{ Bilaterlity } \\
\hline No & $163(57.2 \%)$ & $122(42.8 \%)$ & \multirow{2}{*}{$0.036^{*}$} \\
\hline Yes & $58(46.0 \%)$ & $68(54.0 \%)$ & \\
\hline \multicolumn{4}{|l|}{ Local invasion } \\
\hline No & $188(55.3 \%)$ & $152(44.7 \%)$ & \multirow{2}{*}{0.175} \\
\hline Yes & $33(46.5 \%)$ & $38(53.5 \%)$ & \\
\hline \multicolumn{4}{|l|}{ Aggressive variants } \\
\hline No & $208(52.9 \%)$ & $185(47.1 \%)$ & \multirow{2}{*}{0.108} \\
\hline Yes & $13(72.2 \%)$ & $5(27.8 \%)$ & \\
\hline
\end{tabular}

Table 3. Multivariate analysis of clinicopathologic factors related to lymph node ratio

\begin{tabular}{lcccc}
\hline \multicolumn{1}{c}{ Factors } & Odd ratio & p value & \multicolumn{2}{c}{ Odd ratio (95\% Cl) } \\
\cline { 4 - 5 } Gender & 2.285 & $0.001^{*}$ & 1.415 & Upper \\
Extrathyroidal extension & 1.364 & 0.152 & 0.892 & 2.689 \\
Multifocality & 2.092 & $0.027^{*}$ & 1.086 & 4.030 \\
Bilaterlity & 0.787 & 0.498 & 0.393 & 1.575 \\
\hline
\end{tabular}

$* p<0.05 .95 \% \mathrm{Cl}: 95 \%$ confidence interval 
Table 4. Univariate analysis of clinicopathologic factors related to extranodal extension

\begin{tabular}{|c|c|c|c|}
\hline Characteristics & Extranodal extension (absent) & Extranodal extension (present) & $p$ value \\
\hline \multicolumn{4}{|l|}{ Age } \\
\hline$<45$ yrs & $132(79.5 \%)$ & $34(20.5 \%)$ & \multirow{2}{*}{0.856} \\
\hline$\geq 45 \mathrm{yrs}$ & $193(78.8 \%)$ & $52(21.2 \%)$ & \\
\hline \multicolumn{4}{|l|}{ Gender } \\
\hline Male & $67(71.3 \%)$ & $27(28.7 \%)$ & \multirow{2}{*}{$0.034^{*}$} \\
\hline Female & $258(81.4 \%)$ & $59(18.6 \%)$ & \\
\hline \multicolumn{4}{|l|}{ Size of primary tumor } \\
\hline$<1 \mathrm{~cm}$ & $152(87.9 \%)$ & $21(12.1 \%)$ & \multirow{2}{*}{$0.0002^{*}$} \\
\hline$\geq 1 \mathrm{~cm}$ & $173(72.7 \%)$ & $65(27.3 \%)$ & \\
\hline \multicolumn{4}{|l|}{ Extrathyroidal extension } \\
\hline No & $143(88.3 \%)$ & $19(11.7 \%)$ & \multirow{2}{*}{$0.0002^{*}$} \\
\hline Yes & $182(73.1 \%)$ & $67(26.9 \%)$ & \\
\hline \multicolumn{4}{|l|}{ Multifocality } \\
\hline No & $196(82.0 \%)$ & $43(18.0 \%)$ & \multirow{2}{*}{0.085} \\
\hline Yes & $129(75.0 \%)$ & $43(25.0 \%)$ & \\
\hline \multicolumn{4}{|l|}{ Bilaterlity } \\
\hline No & $229(80.4 \%)$ & $56(19.6 \%)$ & \multirow{2}{*}{0.339} \\
\hline Yes & $96(76.2 \%)$ & $30(23.8 \%)$ & \\
\hline \multicolumn{4}{|l|}{ Local invasion } \\
\hline No & $281(82.6 \%)$ & $59(17.4 \%)$ & \multirow{2}{*}{$0.0001^{*}$} \\
\hline Yes & $44(62.0 \%)$ & $27(38.0 \%)$ & \\
\hline \multicolumn{4}{|l|}{ Aggressive variants } \\
\hline No & $311(79.1 \%)$ & $82(20.9 \%)$ & \multirow{2}{*}{0.890} \\
\hline Yes & $14(77.8 \%)$ & $4(22.2 \%)$ & \\
\hline
\end{tabular}

Table 5. Multivariate analysis of clinicopathologic factors related to extranodal extension

\begin{tabular}{|c|c|c|c|c|}
\hline \multirow{2}{*}{ Factors } & \multirow{2}{*}{ Odd ratio } & \multirow{2}{*}{$p$ value } & \multicolumn{2}{|c|}{ Odd ratio $(95 \% \mathrm{Cl})$} \\
\hline & & & Lower & Upper \\
\hline Gender & 1.706 & 0.057 & 0.984 & 2.956 \\
\hline Size of primary tumor & 1.965 & $0.023^{*}$ & 1.096 & 3.522 \\
\hline Extrathyroidal extension & 1.761 & 0.077 & 0.941 & 3.295 \\
\hline Local invasion & 1.870 & $0.043^{*}$ & 1.020 & 3.428 \\
\hline
\end{tabular}

$* p<0.05 .95 \% \mathrm{Cl}: 95 \%$ confidence interval

3.522)], 국소 침윤 $[p=0.043$, odds ratio $=1.870(95 \% \mathrm{CI}, 1.020$ 3.428)]이 림프절 주변조직 침습과 통계학적으로 유의한 상 관관계를 나타내었다(Table 5).

\section{고 찰}

갑상샘 유두암은 암의 일반적인 특징인 전이나 침습이 흔 하지 않아 전반적인 예후가 아주 좋은 것으로 알려져 있으나 약 30 80\%까지 중심 경부 림프절 전이의 발견을 보고하고 있다. 중심 경부 림프절 전이는 국소 재발이나 원격전이에 영향을 미칠 수 있는 중요한 예후인자이며 인접 구조물의 직
접적인 침범을 하여 불량한 예후의 원인이 될 수 있다. ${ }^{13)}$ 또 한 중심 경부 림프절에 전이암이 재발한 경우에서 재수술은 되돌이 후두 신경이나 부갑상선이 손상될 가능성이 크므로 수술에 의한 합병증의 빈도가 증가하게 된다. ${ }^{14)}$ 갑상샘 유두 암에서 중심 경부 림프절 전이의 위험도가 증가하는 경우는 다발성 종양을 가진 경우, 종양의 크기 $5 \mathrm{~mm}$ 이상인 경우, 남 성인 경우, 나이가 45 세 이하인 경우, 갑상샘 피막외 침범이 있 는 경우로 알려져 있다. ${ }^{6,7)}$

최근의 보고에 따르면 절제된 림프절에 대한 전이된 림프 절의 비율이 높거나 림프절 피막외 침범이 동반된 경우 높은 국소 재발률을 보이는 것으로 보고되고 있다. ${ }^{8-12)}$ 절제된 림 
프절에 대한 전이된 림프절의 비율은 위암, 대장암에서는 중 요한 예후인자이지만 갑상샘 유두암에서는 상관관계가 불명 확하였다. 하지만 최근의 연구 결과에서는 절제된 중심 경부 림프절에 대한 전이된 림프절의 비율이 높은 경우 통계적으 로 유의한 높은 국소 재발률과 낮은 생존율을 보이는 것으로 보고된 바 있다. ${ }^{8-10)}$ Vas Nunes 등 ${ }^{8)}$ 은 절제된 경부 림프절에 대한 전이된 림프절의 비율이 $1 / 3$ 이상인 군에서 무병 생존율 이 의미 있게 낮다고 보고하였으며 Schneider 등흔 절제된 경부 림프절에 대한 전이된 림프절의 비율이 0.42 이상일 때 유의하게 사망률이 높아진다고 보고하였다. 기준점이 되는 전 이된 림프절의 비율 및 비율에 따른 등급 체계는 향후 정립 이 필요하며 본 연구에서는 절제된 림프절에 대한 전이된 림 프절의 비율의 기준을 $1 / 2$ 로 하였다. 중심 경부 림프절에 대 한 전이된 림프절의 비율을 구하여 그 비율이 $1 / 2$ 미만인 군 과 $1 / 2$ 이상인 두 군으로 나누어 임상양상 차이 여부를 확인 하였으며 절제된 림프절에 대한 전이된 림프절의 비율이 $1 / 2$ 이상일 경우는 남성, 종양의 다발성이 통계학적으로 유의한 상관관계를 나타내었다.

갑상샘 유두암의 림프절 전이 병소는 때때로 림프절의 피 막을 넘어 주변 연부조직으로 침범한다. 실제 림프절 전이 병소 의 주변 연부조직으로의 침범 여부는 두경부암의 수술 후 방 사선 치료 여부를 결정하는 주요 인자 중 하나이고 국소 재발 률의 예측인자이기도 하다. ${ }^{11,12}$ 림프절 전이 병소의 림프절 피 막외 침범은 세 가지로 나눌 수 있다. 첫 번째는 현미경에서 확인 가능한 미세한 크기의 림프절 피막외 침범이고 두 번째 는 육안으로 확인 가능한 비교적 크기가 큰 림프절 피막외 침범, 그리고 세 번째는 전이 병소가 림프절을 완전히 대치하 여 림프절의 구조가 남아 있지 않거나 실제로 림프절과는 관 계없는 연부조직으로의 전이성 병변인 경우이다. ${ }^{15)}$ 이 중 첫 번째와 두 번째와 같은 림프절 피막외 침범의 경우도 통계적 으로 유의한 높은 국소 재발률과 낮은 생존율을 보이는 것으 로 보고된 바 있다.11) 또 다른 보고에서는 육안적인 림프절 피막외 침범뿐 아니라 현미경적인 림프절 피막외 침범의 경 우에도 전체 생존율이 낮았으며 ${ }^{12)}$ 이러한 림프절의 개수가 3 개 이상일 때 수술 후에도 환부의 요오드 섭취가 지속적으로 관찰되는 현상(persistent disease)이 유의하게 증가한다는 결과를 보였다. ${ }^{16)}$ 이번 연구에서는 중심 경부 림프절 전이가 있는 갑상샘 유두암 환자들을 대상으로 절제된 전이 림프절 에서 림프절 피막외 침범은 원발 부위의 크기가 $1 \mathrm{~cm}$ 이상, 국소 침윤이 있을 경우에 통계학적으로 유의한 상관관계를 나타내었다.

본 연구에서는 수술 후 추적기간이 길지 않아 갑상샘 유두 암에 있어 절제된 중심 경부 림프절에 대한 전이된 림프절의
비율, 림프절 피막외 침범과 국소 재발, 원격전이, 예후의 상 관관계를 파악할 수는 없었으나 장기간의 추적관찰이 이루 어진다면 예후 및 예후인자에 대한 보다 더 정확한 자료를 얻 을 수 있을 것으로 생각되며, 이에 따른 적절한 치료계획을 수 립할 수 있을 것으로 생각한다.

갑상샘 유두암은 경부 림프절로 전이가 잘 되기 때문에 예 측 가능한 전이형태에 대한 명확한 이해가 있어야 적절한 수 술적 치료가 가능하다. 본 연구에서 전이 림프절 비율, 림프절 피막외 침범과 유의성이 확인된 남성, 다발성 종양, $1 \mathrm{~cm}$ 이상 의 원발부위 종양, 국소 침윤이 있는 환자들에게는 좀 더 철 저한 중심 경부 림프절 절제술의 시행이 국소재발을 줄이는 데 있어 중요할 것으로 생각된다.

\section{REFERENCES}

1) Shaha AR, Shah JP, Loree TR. Patterns of nodal and distant metastasis based on histologic varieties in differentiated carcinoma of the thyroid. Am J Surg 1996;172:(6)692-4.

2) Attie JN. Modified neck dissection in treatment of thyroid cancer: a safe procedure. Eur J Cancer Clin Oncol 1988;24(2):315-24.

3) Lundgren CI, Hall P, Dickman PW, Zedenius J. Clinically significant prognostic factors for differentiated thyroid carcinoma: a population-based, nested case-control study. Cancer 2006;106(3): 524-31.

4) Harwood J, Clark OH, Dunphy JE. Significance of lymph node metastasis in differentiated thyroid cancer. Am J Surg 1978;136(1): $107-12$.

5) Machens A, Hinze R, Thomusch O, Dralle H. Pattern of nodal metastasis for primary and reoperative thyroid cancer. World J Surg 2002;26(1):22-8.

6) Clark OH. Thyroid cancer and lymph node metastases. J Surg Oncol 2011;103(6):615-8.

7) Chow SM, Law SC, Chan JK, Au SK, Yau S, Lau WH. Papillary microcarcinoma of the thyroid-Prognostic significance of lymph node metastasis and multifocality. Cancer 2003;98(1):31-40.

8) Vas Nunes JH, Clark JR, Gao K, Chua E, Campbell P, Niles N, et al. Prognostic implications of lymph node yield and lymph node ratio in papillary thyroid carcinoma. Thyroid 2013;23(7):811-6.

9) Schneider DF, Chen H, Sippel RS. Impact of lymph node ratio on survival in papillary thyroid cancer. Ann Surg Oncol 2013;20(6): 1906-11.

10) Schneider DF, Mazeh H, Chen H, Sippel RS. Lymph node ratio predicts recurrence in papillary thyroid cancer. Oncologist 2013;18(2):157-62.

11) Ito $Y$, Hirokawa M, Jikuzono T, Higashiyama T, Takamura $Y$, Miya A, et al. Extranodal tumor extension to adjacent organs predicts a worse cause-specific survival in patients with papillary thyroid carcinoma. World J Surg 2007;31(6):1194-201.

12) Ricarte-Filho J, Ganly I, Rivera M, Katabi N, Fu W, Shaha A, et al. Papillary thyroid carcinomas with cervical lymph node metastases can be stratified into clinically relevant prognostic categories using oncogenic BRAF, the number of nodal metastases, and extra-nodal extension. Thyroid 2012;22(6):575-84.

13) Pelizzo MR, Boschin IM, Toniato A, Pagetta C, Piotto A, Bernante $\mathrm{P}$, et al. Natural history, diagnosis, treatment and outcome of papillary thyroid microcarcinoma (PTMC): a mono-institutional 12-year experience. Nucl Med Commun 2004;25(6):547-52.

14) Noguchi M, Earashi M, Kitagawa H, Ohta N, Thomas M, Miyazaki I, et al. Papillary thyroid cancer and its surgical management. J Surg Oncol 1992;49(3):140-6. 
15) Min HS. N stage: controversies and recent issues. J Korean Thyroid Assoc 2012;5(2):109-13.

16) Leboulleux S, Rubino C, Baudin E, Caillou B, Hartl DM, Bidart JM, et al. Prognostic factors for persistent or recurrent disease of papillary thyroid carcinoma with neck lymph node metastases and/ or tumor extension beyond the thyroid capsule at initial diagnosis. J Clin Endocrinol Metab 2005;90(10):5723-9. 